\title{
Pengaruh Temperatur Ekstraksi dan Heating Timeterhadap Spectrum Absorbansi pada Zat Warna Alam dari Kayu Secang
}

\author{
Subur Mulyanto \\ Teknik Mesin \\ Politeknik Negeri Balikpapan \\ J1. Soekarno-Hatta Km.8 - Balikpapan \\ subur.mulyanto@poltekba.ac.id,
}

\begin{abstract}
The purpose of this study to analyze the extraction process with variations of the temperature and heating time on the extraction of natural dyes from caesal pinia sappan. Extraction processof the sappan wood used capacity of 150 liters on the variation of temperature and time of extraction at $70{ }^{\circ} \mathrm{C} ; 80{ }^{\circ} \mathrm{C} ; 90{ }^{\circ} \mathrm{C} ; 100{ }^{\circ} \mathrm{C}$ and water-soluble. FTIR spetrofotometer test was conducted to identify the composition of functional groups brazilein compound, while the Uv-Vis spectrophotometer is used to view the absorbance spectrum, so it can then do an analysis of the influence of time and temperature on the extraction of red natural dye absorbance specrum. Results infrared spectrophotometer shows some absorption area in order to identify functional groups of compounds brazilein, namely the absorption at wavenumber 650-1000 showed a group $=C-H$, at wavenumber 1000-1300 showed a group $\mathrm{C}-\mathrm{O}-\mathrm{C}$ and $\mathrm{C}-\mathrm{OH}$, at wavenumber 1550-1650 showed a group $\mathrm{C}=\mathrm{C}$, and at a wavenumber 1650-1800 showed a group $C=O$. On Uv-Vis spectrophotometer is known that the maximum absorbance was obtained at the time of 2 hours at a temperature of $80{ }^{\circ} \mathrm{C}$ and $90{ }^{\circ} \mathrm{C}, U v$-Vis spectrophotometer at various temperatures rise significantly absorbance occurs at a temperature of $70^{\circ} \mathrm{C} s . / d$. $90^{\circ} \mathrm{C}$ at 2 hours.
\end{abstract}

Keywords :Caesalpinia Sappan Linn, Brazilein, Absorbance,UV-Vis Spektrofotometer

\begin{abstract}
Abstrak
Penelitian ini bertujuan untuk melakukan analisa terhadap proses ekstraksi dengan variasi temperatur ekstraksi dan heating time pada zat warna alam dari kayu secang. Proses ekstraksi kayu secang berkapasitas 150 liter dengan variasi waktu dan temperatur ekstraksi pada $70{ }^{\circ} \mathrm{C} ; 80{ }^{\circ} \mathrm{C} ; 90{ }^{\circ} \mathrm{C} ; 100{ }^{\circ} \mathrm{C}$ menggunakan pelarut air. Uji spetrofotometer FTIR dilakukan untuk mengidentifikasi susunan gugus fungsi senyawa brazilein, sedangkan spektrofotometer Uv-Vis digunakan untuk melihat spektrum absorbansi, sehingga kemudian dapat dilakukan analisa tentang pengaruh waktu dan temperatur ekstraksi terhadap spektrum absorbansi ZWA merah secang. Hasil spektrofotometer infra merah menunjukkan beberapa daerah serapan sehingga dapat diidentifikasi gugus fungsi dari senyawa brazilein, yaitu serapan pada wavenumber 650-1000 menunjukkan adanya gugus $=\mathrm{C}-\mathrm{H}$, pada wavenumber 1000-1300 menunjukkan adanya gugus $\mathrm{C}-\mathrm{O}-\mathrm{C} \& \mathrm{C}-\mathrm{OH}$, pada wavenumber 1550-1650 menunjukkan adanya gugus $C=C$, dan pada wavenumber 1650-1800 menunjukkan adanya gugus $C=O$. Pada spektrofotometer Uv-Vis diketahui bahwa absorbansi maksimum diperoleh pada waktu 2 jam yaitu pada temperatur $80^{\circ} \mathrm{C}$ dan $90^{\circ} \mathrm{C}$, spektrofotometer Uv-Vis pada variasi temperatur kenaikan absorbansi secara signifikan terjadi pada temperatur $70^{\circ} \mathrm{C} s . / d .90^{\circ} \mathrm{C}$ pada waktu 2 jam.
\end{abstract}

Kata kunci :Kayusecang, Brazilein, Absorbansi, SpektrofotometerUv-Vis

\section{Pendahuluan}

Indonesia yang kaya akan bahan alam pernah mengalami kejayaan dalam hal produksi zat warna alam (ZWA). ZWA merupakan zat warna yang berasal dari tumbuhan maupun hewan yang diekstrak dengan menggunakan air sehingga ketersediaanya dapat diperbarui.Terdapat sekitar 150 jenis tanaman yang intensif menghasilkan pewarna alam.Warna yang dihasilkan meliputi warna dasar (merah, biru, kuning) dan warna-warna kombinasi seperti coklat, jingga, dan nila (Heyne 1988). Para pengrajin batik di Indonesia telah banyak mengenal beberapa tanaman yang dapat mewarnai batik beberapa diantaranya adalah: daun indigo (Indigofera Tictoria L), kayu tegeran (Cudrainajavanensis), kayu secang 
(Caesalpinia Sappan Linn), kulit pohon sogatingi(Ceriopscandolleanaarn), kunyit (Curcuma), the (The), akar mengkudu (Morindacitrifelia), kulit soga jambal (Pelthophorumferruginum), dan kesumba (Bixaorelana). Dari keseluruhan jenis tumbuhan yang digunakan sebagai penghasil zat warna. Adapun selain belum teruji nya ketahanan luntur dan harga yang belum kompetitif juga masih terkesan kusam jika melihat tampilan warna setelah zat warna tersebut di aplikasikan pada kain, salah satunya adalah ekstrak dari kayu secang yang menghasilkan warna merah.

Selain untuk bahan minuman kesehatan, kayu secang (Caesalpinia Sappan L) juga telah banyak dijadikan sebagai bahan baku pewarna alami untuk makanan maupun tekstil. Bagian yang diambil sebagai bahan pewarna alami yaitu pada batang kayunya. Ekstrak kayu secang ini memiliki warna merah. Namun dalam kenyataannya menunjukkan bahwa kondisi $\mathrm{pH}$ mempengaruhi warna merah dari ekstrak kayu secang. Sehingga pada kondisi $\mathrm{pH}$ tertentu ekstrak kayu secang juga dapat memberikan warna selain merah, seperti warna ungu dan kuning.

Tabel. 1.1. Warna pigmen secang terhadap kondisi $\mathrm{pH}$

\begin{tabular}{cl}
\hline $\mathbf{p H}$ & Warna \\
\hline $2-5$ & Kuning orange \\
$6-7$ & Merahmuda \\
$>7$ & Merahkeunguan \\
\hline
\end{tabular}

Warna merah secang ditimbulkan oleh senyawa kimia yang bernama brazilein yang merupakan hasil oksidasi dari senyawa yang bernama brazilin. Brazilin yang semula berwarna kuning akan menjadi warna merah dan larut dalam air jika teroksidasi (Y. Min 2006). Kedua komponen brazilin dan brazilein merupakan tetrasiklik dengan dua cincin aromatik, satu piron, dan satu cincin lima karbon (Luiz F.C. de Oliveiraa 2002). Berikut ini adalah struktur kimia dari brazilein dan brazilin. Warna kuning brazilin yang berubah menjadi brazilein kemerahan disebabkan karena adanya peningkatan delokalisasi elektron karena keberadaan gugus karbonil. Warna merah brazilien pada kayu secang baik digunakan untuk pewarna katun atau wol (Ghobadian 2007).

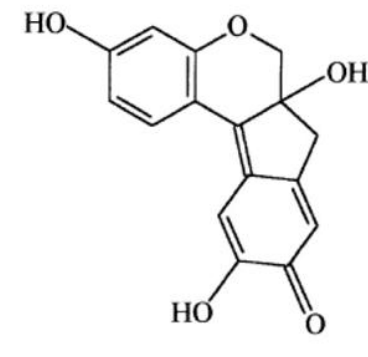

Brazilein

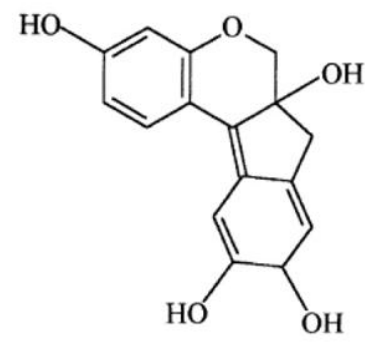

Brazilin
Gambar 1.1. Struktur kimia brazilin (a) dan brazilein (b) (Wongsookin 2008)

\section{Metode Penelitian}

Peralatan yang digunakan dalam penelitian ini antara lain, crusher untuk mencacah bahan sebelum diekstrak, reaktor kapasitas 150 liter dengan pengatur suhu, alat penyaring, vacuum rotary evaporator, spektrofotometer Uv-Vis rayleigh $u v-1800$, dan spektrofotometer infra merah FTIR shimadzhu. Adapun bahan yang digunakan adalah kayu secang dengan kadar air $13-14 \%$ dan menggunakan pelarut air.

Kayu secang yang sudah dicacah dimasukkan ke dalam reaktor bersama dengan pelarut kemudian dipanaskan selama 3 jam. Proses ekstraksi ini dilakukan dengan variasi temperatur yaitu, $70^{\circ} \mathrm{C}, 80^{\circ} \mathrm{C}, 90^{\circ} \mathrm{C}$, dan $100^{\circ} \mathrm{C}$. Pada masing-masing variasi temperatur ekstraksi diambil sampel ekstrak $10 \mathrm{ml}$ setiap 30 menit untuk pengukuran 
absorbansi dengan spektrofotometer UvVis. Setelah selesai proses ekstraksi pada masing-masing variasi temperatur juga diambil sampel yang akan diidentifikasi gugus fungsi senyawa kimianya dengan uji spektrofotometer infra merah (FTIR).

\section{Hasil dan Pembahasan}

\subsection{Uji Spektrofotometri Infra Merah}

Pengujian Spektrofotometer infra merah dilakukan untuk mengidentifikasi susunan gugus senyawa kimia brazilein yang terdapat pada ZWA merah secang. Pengujian ini akan membuktikan bahwa warna merah yang dihasilkan dari ZWA merah secang adalah senyawa brazilein. Hasil spektrofotometer infra merah menunjukkan beberapa daerah serapan sehingga dapat diidentifikasi gugus fungsi dari senyawa brazilein, yaitu serapan pada wave number 650-1000 menunjukkan adanya gugus $=\mathrm{C}-\mathrm{H}$, pada wave number 1000-1300 menunjukkan adanya gugus $\mathrm{C}-$ $\mathrm{O}-\mathrm{C} \& \mathrm{C}-\mathrm{OH}$, pada wavenumber $1550-$ 1650 menunnjukkan adanya gugus $\mathrm{C}=\mathrm{C}$, dan pada wavenumber 1650-1800 menunjukkan adanya gugus $\mathrm{C}=\mathrm{O}$. Berdasarkan hasil identifikasi, bahwa gugus yang ditunjukkan pada masingmasing daerah serapan merupakan gugus fungsi senyawa kimia brazilein. Gambar 3.1 menunjukkan spektrofotometer infra merah ZWA merah secang dengan variasi temperature kstraksi.

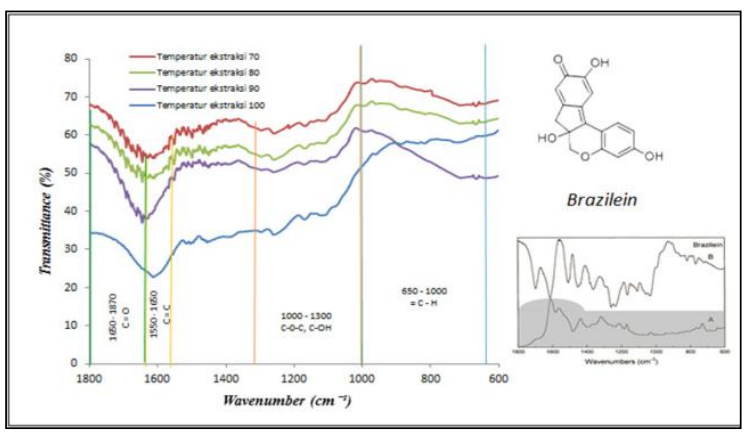

Gambar 3.1 Spektrofotometer infra merah ZWA merahsecang

\subsection{Uji Spektrofotometri UV-Vis}

Spektrofotometer Uv-Vis digunakan untuk mengetahui spektrum absorbansi ZWA merah secang pada panjang gelombang 400-800 nm. Dengan hasil uji tersebut dapat dianalisa spektrum absorbansi dari masing-masing variasi sampel ekstrak kayu secang yang sudah menjadi ZWA merah secang.

\subsection{Menentukan heating time ekstraksi}

Menentukan konsentrasi maksimum berdasarkan pada absorbansi yang ditunjukkan pada hasil pengujian spektrofotometer Uv-Vis. Dari hasil uji tersebut dapat diketahui berapa waktu yang dibutuhkan untuk proses ekstraksi ZWA merah secang dengan melihat absorbansi dari setiap variasi waktu. Gambar 3.2 menunjukkan bahwa rata-rata setelah 2 jam ekstraksi, ZWA merah secang tidak mengalami peningkatan absorbansi secara signifikan. Sehingga untuk mendapatkan konsentrasi ZWA merah secang atau kepekatan warna merah maksimum dibutuhkan waktu ekstraksi selama 2 jam. Pada gambar 3.2 juga menunjukkan adanya pergeseran panjang gelombang, terlihat bahwa semakin tinggi temperatur ekstraksi maka panjang gelombang juga semakin jauh.

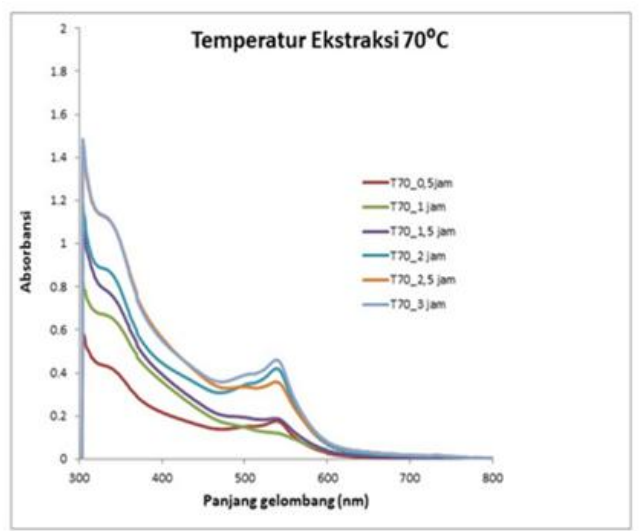



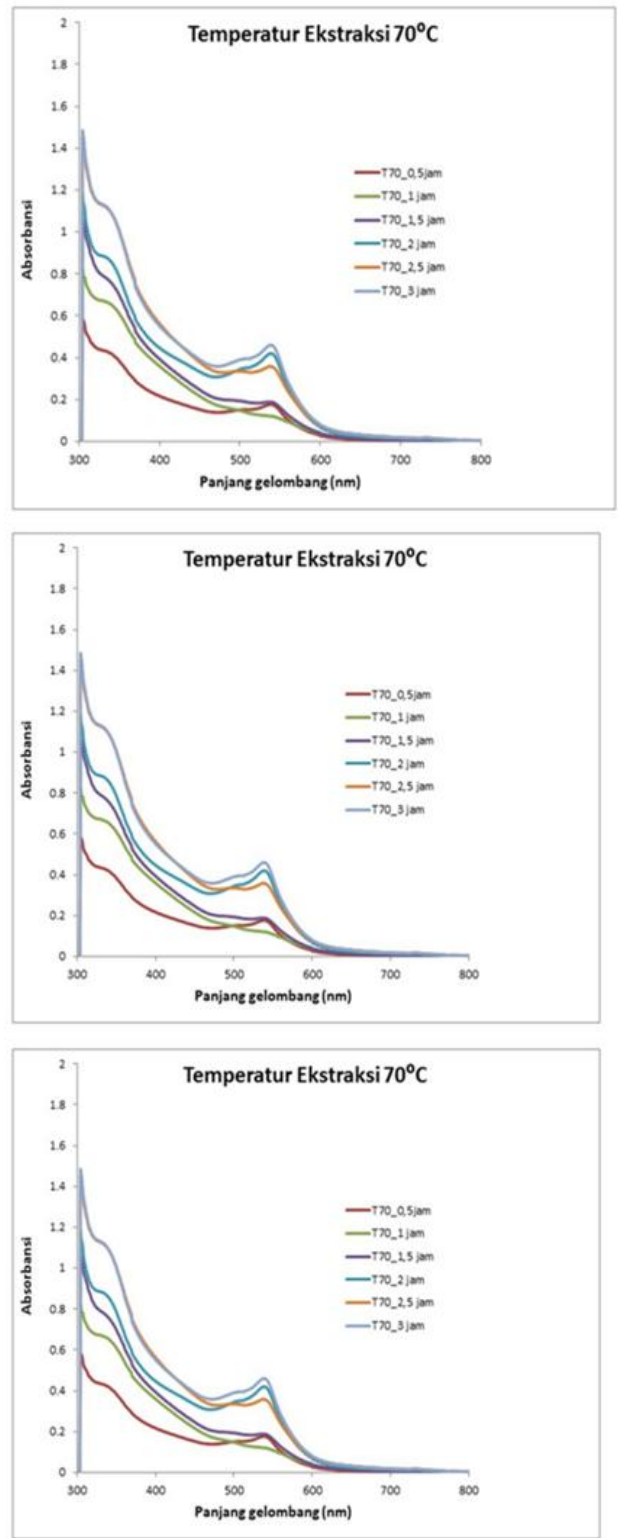

Gambar 3.2. Spektrum UV-Vis dengan variasi waktu ekstraksi pada masing-masing temperatur.

Tabel 3.1 Menunjukkan absorbansi maksimal dari masing-masing variasi temperatur dengan variasi waktu ekstraksi. Dari data tersebut tampak bahwa setelah waktu ekstrak melampaui 2 jam, selisih absorbansi maksimal tidak terlalu besar sehingga pengaruh bertambah konsentrasi atau kepekatan warna relatif kecil. Terlihat juga bahwa semakin tinggi temperatur ekstraksi maka puncak absorbansi maksimal akan semakin mengalami pergeseran panjang gelombang yang semakin jauh pula, yang berarti ZWA merah secang tersebut mengalami perubahan warna sesuai dengan panjang gelombangnya masing-masing.

Tabel 3.1. Hasil Uji UV Vis ekstrak kayu secang dengan variasi waktu dan temperatur

\begin{tabular}{|c|c|c|c|c|c|c|c|c|}
\hline \multirow{3}{*}{$\begin{array}{l}\text { Waktu } \\
\text { (jam) }\end{array}$} & \multicolumn{8}{|c|}{$\mathrm{A}$ (maks) } \\
\hline & \multicolumn{2}{|c|}{$\mathrm{T} 70$} & \multicolumn{2}{|c|}{ T80 } & \multicolumn{2}{|c|}{ T90 } & \multicolumn{2}{|c|}{ T100 } \\
\hline & $\lambda$ & $\mathrm{A}$ & $\lambda$ & $\mathrm{A}$ & $\lambda$ & $\mathrm{A}$ & $\lambda$ & $\mathrm{A}$ \\
\hline 0,5 & 538 & 0.18 & 500 & 0.23 & 539 & 0.43 & 539 & 0.6 \\
\hline 1 & 466 & 0.18 & 500 & 0.47 & 540 & 0.77 & 538 & 0.79 \\
\hline 1,5 & 500 & 0.19 & 501 & 0.8 & 541 & 1.24 & 539 & 1.39 \\
\hline 2 & 539 & 0.42 & 538 & 1.06 & 540 & 1.67 & 539 & 1.55 \\
\hline 2,5 & 539 & 0.36 & 536 & 1 & 540 & 1.74 & 546 & 1.8 \\
\hline 3 & 539 & 0.46 & 538 & 0.78 & 540 & 1.64 & 558 & 1.67 \\
\hline
\end{tabular}

\subsection{Absorbansi Zat Warna Secang}

Sebagaimana hasil analisa sebelummnya, bahwa diperoleh waktu ekstrak kayu secang dengan konsentrasi maksimum yaitu selama 2 jam, maka selanjutnya dilakukan analisa untuk mengetahui perbandingan absorbansi dari masing-masing temperatur ekstraksi kayu secang. Perbandingan konsentrasi atau kepekatan warna mengambil data dari hasil spektrofotometer UV-Vis dengan beberapa perbandingan proses ekstraksi. Perbandingan yang dimaksud adalah pada variasi temperatur ekstraksinya, yaitu pada suhu $70^{\circ} \mathrm{C}, 80^{\circ} \mathrm{C}, 90^{\circ} \mathrm{C}$, dan $100^{\circ} \mathrm{C}$ dengan waktu ekstraksi masing-masing 2 jam. Sehingga pada Gambar 3.2 menunjukkan semakin besar suhu ekstraksi maka nilai absorbansi semakin tinggi, hal ini menandakan bahwa konsentrasi zat warna di dalam pelarut semakin tinggi atau warna yang dihasilkan semakin pekat. Sejalan dengan gambar 3.1 dan tabel 3.1, bahwa semakin besar temperatur ekstaksi semakin jauh panjang gelombang begeser atau semakin jauh. Karena berakibat pada perubahan warna, maka pergeseran panjang gelombang ini tidak dikehendaki. Dari gambar 3.1 dapat diketahui bahwa selain waktu ekstraksi, temperatur juga memiliki pengaruh terhadap absorbansi zat warna merah secang. 


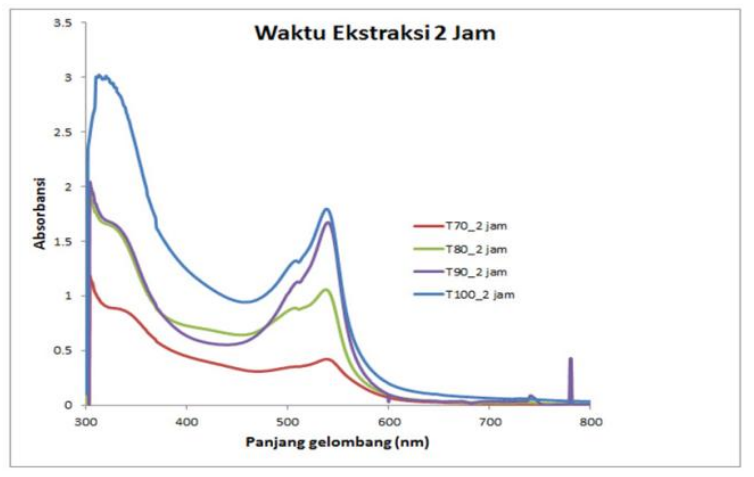

Gambar 3.3. Spektrum UV Vis ZWA merah secang dengan variasi temperatur.

\section{Kesimpulan}

Berdasarkan pada hasil pengujian dan analisa yang sudah dilakukan, maka dapat disimpulkan bahwa temperature dan waktu ekstraksi ZWA merah secang memiliki pengaruh terhadap spectrum absorbansi.

Spektrum Uv-Vis pada variasi waktu menunjukkan bahwa pada temperature ekstraksi $70^{\circ} \mathrm{C}$ memiliki absorbansi yang rendah hingga 3 jam, pada temperature ekstraksi $80^{\circ} \mathrm{C}$ dan $90^{\circ} \mathrm{C}$ spectrum absorbansiya maksimum pada waktu 2 jam, dan pada temperature ekstraksi $100^{\circ} \mathrm{C}$ spectrum absorbansinya maksimum pada waktu 1 jam 30 menit, akan tetapi pada variasi ini warna mengalami kerusakan karena terjadi pergeseran panjang gelombang setelah waktu ekstrak mencapai 3 jam

Sedangkan spectrum Uv-Vis pada variasi temperature menunjukkan bahwa semakin tinggi temperature ekstraksi semakin tinggi absorbansi, akan tetapi kenaikan absorbansi yang signifikan hanya terjadi pada temperature ekstraksi $70^{\circ} \mathrm{C} \quad$ s./d. $90^{\circ} \mathrm{C}$.

\section{Saran}

Perlu adanya penelitian dalam tentang zat warna alam untuk meneliti lebih lanjut pada analisa gugus dan pengaruhnya pada energi alternatif seperti penerapan zat warna alam dalam DSSC (Dyes Sensitized Solar Cell).

\section{DaftarPustaka}

Ghobadian, G. R. C. a. B. (2007). "Spray Dryer Parameters for Fruit Juice Drying." World Journal of Agricultural Sciences 3.

Heyne, K. (1988). Tumbuhanberguna Indonesia, YayasanSaranaWanaJaya :DiedarkanolehKoperasiKaryawan, DepartemenKehutanan.

Luiz F.C. de Oliveiraa, H. G. M. E., Eudes S. Velozoc, M. Nesbittd (2002). "Vibrational spectroscopic study of brazilin and brazilein, the main constituents of brazilwood from Brazil." Vibrational Spectroscopy 28(2).

Wongsookin, K., Saowanee, R., Malee, T., Vichitr, R., and John, B. B. (2008). "Study of an Al(III) complex with the plant dye brazilein fromCaesalpiniasappan Linn." Journal Science Technology 15.

Y. Min, W., D. X., Fan, L., Zheng, M., $Y u$, N. Z., Hui, S., and Li, J. D (2006). "Brazilin an important immunosuppresivecomponenfromCaesa Ipinia Sappan L." Journal International Immunopharm 6 